\title{
PUPAL EMERGENCE INHIBITION ACTIVITY OF ACALYPHA INDICA LEAF EXTRACT AGAINST DENGUE VECTOR, AEDES ALBOPICTUS MOSQUITO
}

\author{
ASHWINI U. ${ }^{1}$, TAJU G. ${ }^{2}$, THIRUNAVUKKARASU P. ${ }^{3}$, ASHA S. ${ }^{*}$ \\ 1Department of Biochemistry, D. K. M. College for Women (Autonomous), Sainathapuram, Vellore, Vellore DT, Tamil Nadu 632001, \\ ${ }^{2}$ Department of Biotechnology, C. Abdul Hakeem College, Melvisharam, Vellore, Vellore DT, Tamil Nadu 632509, ${ }^{3}$ Department of \\ Biotechnology, Dr. M. G. R. Educational and Research Institute University, Maduraivoyal,Chennai-95 \\ Email: asha.sivaji@gmail.com
}

Received: 23 Apr 2017 Revised and Accepted: 19 Jun 2017

\begin{abstract}
Objective: To investigate the larvicidal activities of six varying extracts of Acalypha indica (A. indica) leaves from family Euphorbiaceae against the dengue mosquito vector, Aedesalbopictus (Ae. albopictus) in laboratory.

Methods: Leaves from the study plants were separated, air dried in room temperature, grounded and extracted with different solvents (petroleum ether, chloroform, ethyl acetate, n-butanol, ethanol and aqueous) by solvent apparatus and aqueous extract by maceration method. The extra solvents were evaporated to obtain crude extracts by using rotary evaporator. The crude extracts of six different solvents were dissolved in dimethyl sulphoxide (DMSO) to prepare test dosages of 1000, 2000, 3000, 4000 and $5000 \mathrm{ppm}$. Third instar larvae of Ae. albopictus were exposed to $1000,2000,3000,4000$ and 5000 ppm concentrations of petroleum ether, chloroform, ethyl acetate, n-butanol, ethanol and aqueous extracts of $A$. indica and compared with control to determine the larvicidal effects. Larval bioassays were carriedout according to World Health Organisation (WHO) procedures. The rate of larval mortality was recorded after $24 \mathrm{~h}$ and $48 \mathrm{~h}$ of time exposure. Three duplicate trials were made for each tested dosage. IC50 and IC90 values were calculated by using probit analysis.

Results: Based on probit analysis result the $24 \mathrm{~h}$ and $48 \mathrm{~h}$ LC50 and LC90 of petroleum ether extract of A. indica against Ae. albopictus was found to be $2805.43 \mathrm{ppm}$ and $2376.11 \mathrm{ppm}, 3825.14 \mathrm{ppm}$ and $3327.8 \mathrm{ppm}$, respectively. An LC50 and LC90 value of chloroform extracts of $A$. indicaa gainst third instar larvae was found to be $2276.5 \mathrm{ppm}$ and $4015.8 \mathrm{ppm}(24 \mathrm{~h}), 2213.36 \mathrm{ppm}$ and $3430.43 \mathrm{ppm}$ (48h), respectively. An LC50 value of $4472.17 \mathrm{ppm}$ and $2469.61 \mathrm{ppm}$, and LC90 value of $4215.84 \mathrm{ppm}$ was obtained on ethylacetate extract treatment against Ae. albopictus for $24 \mathrm{~h}$ and $48 \mathrm{~h}$ exposure, respectively. The $24 \mathrm{~h}$ and $48 \mathrm{~h} \mathrm{LC50}$ and LC90 values of n-butanol extracts of $A$. indica was found to be $2777.88 \mathrm{ppm}$ and 3628.19 ppm, $2225.61 \mathrm{ppm}$ and $2518.86 \mathrm{ppm}$, respectively. In the present study, the larvicidal bioassays demonstrated that the n-butanolextract was most effective with 100\% mortality against larvae of Ae. albopictus at 3000, 4000 and $5000 \mathrm{ppm}$ compared to other extracts. All other extracts (petroleum ether, chloroform and ethyl acetate) of $A$. indica at high concentration (4000 ppm and $5000 \mathrm{ppm})$ manifested a significant $(\mathrm{P}<0.01$ and 0.05 ) knock down effect of $100 \%$ moratality after $24 \mathrm{~h}$ and $48 \mathrm{~h}$ exposure. While the third instar lavae of Ae. albopictus were found to be most susceptabile and produced no mortality to ethanol and aqueous extract at varying parts per million.
\end{abstract}

Conclusion: A. indica leaf extract was tested for the first time against dengue vector Ae. albopictus and the results revealed that $A$. indica can be used to control dengue vector. Further this extract needs to be evaluated under field conditions for proper exploitation of Ae. albopictus mosquito larvae. Thus, the present study provided a first report on A. indica as a prompting mosquito larvicidal activity and can be considered for further investiagtions such as formulation of bioinsecticides to control Ae. albopictus populations.

Keywords: Mosquito, Ae. albopictus, Larvae, Medicinal plants, Diseases, Insecticides

(C) 2017 The Authors. Published by Innovare Academic Sciences Pvt Ltd. This is an open access article under the CC BY license (http://creativecommons.org/licenses/by/4.0/) DOI: http://dx.doi.org/10.22159/ijpps.2017v9i8.19362

\section{INTRODUCTION}

Mosquitoes, the most important agent as vector transmits several serious human diseases like malaria, filariasis, japanese encephalitis, dengue fever, chikungunya and yellow fever [1-3] and several diseases as a major public health problem in the world. The current mosquito control strategies are mainly focussed on synthetic insecticides considered as the first line of action against mosquito vectors. Besides itstoxic nature continuous usage of synthetic insecticides causes ecological imbalance, environmental pollution by contaminating soil, water and air [4], destruction of non-target organisms including humans and animals $[5,6]$ and development of insecticide resistance in target insects [7]. Because of the undesirable side effects of the synthetic chemical pesticides, natural insecticides development achieved as an alternative way in mosquito control programs. Plants acts as an excellent source for the reduction of mosquito population at all the stages due to their excellent larvicidal, pupicidal and adulticidal properties. The use of plant extracts has natural insecticides due to the presence of several appealing features like less hazardous, non-toxic, safer for non-target organisms, target specific activity, biodegradable and rich bioactive chemicals [8-12]. Green larvicides are of great importance and considered now because of presence of several bioactive components while the conventional insecticide comprises single active ingradient. These properties has stimulated many investigators to investigate about natural insecticides and also many researchers have reported the effectiveness of various plant against mosquito larvae.

Previous studies have evaluated the potential use of plants such as $C$. obtusifolia[13], Trachyspermunammi [14] against An. stephensi, Piper longum and Piper nigrum [15,16], Cassia fistula [17], Coriandrum sativum [18] against Ae. aegypti, $P$. nigrum against Culex quinquefasciatus [19], Cassia siamea against Plasmodium berghei [20], Cassia auriculata against An. stephensi and Culex quinquefasciatus[21] Lantana camera against Ae. aegypti, Culex quinquefasciatus, An culicifacies, An. fluvialitis and An stephensi [22], L. camera against Ae. albopictus and Ae. aegypti [23] as larvicidal activity.

Mosquito mostly belongs to genera Anopheles, Aedes and Culex as vectors for pathogens of various diseases. Among the mosquitoes $A e$ albopictus (Diptera: Culicidae), a competent vector of Aedesaegypti causes chikungunya and dengue viruses, highly dangerous to human health [24]. Very few studies have been carried out on Ae. albopictus mosquitoes over a long period [25-28] hence the present study is focused on this species. Keeping these points in view, in this context, the purpose of the present investigation is to explore the larvicidal 
activity of $A$. indica leaf extract against Ae. albopictus under the laboratory conditions. Therefore, this study provides the first report on the mosquito larvicidal activity effect of $A$. indica leaf extract against third instar larvae of Ae. albopictus as target species.

\section{MATERIALS AND METHODS}

\section{Chemicals and reagents}

All the solvents and other reagents used in the present study are of analytical grade and purchased from Sigma-Aldrich Co.

\section{Collection of plant materials}

The leaf of $A$. indica (family: Euphorbiaceae) was collected in and around Velapadi $\left(12^{\circ} 56^{\prime} 5.8^{\prime \prime} \mathrm{N}\right.$ and $\left.79^{\circ} 8^{\prime} 48.7716^{\prime \prime} \mathrm{E}\right)$, Vellore district, India. The collected materials were identified by using the standard taxonomic key. The Voucher specimen (No. 1316) was deposited and kept in our Herbarium for further reference.

\section{Preparation of plant extract}

A. indica plant was washed with tap water and then followed by distilled water to remove the sand particles. Leaves were separated, air dried in shade for 20-30 d at environmental temperature. The shade dried materials were grounded into fine powder using a electrical stainless steel blender and stored in air tight bottles until further use.

\section{Extraction method}

From the $A$. indica leaf powder $30 \mathrm{~g}$ of weight quantity was extracted with petroleum ether $(250 \mathrm{ml}$, Qualigens chemicals, India. $)$ Chloroform ( $400 \mathrm{ml}$,Qualigens chemicals, India), Ethyl acetate (300 $\mathrm{ml}$, Qualigens chemicals, India), n-Butanol $(350 \mathrm{ml}$ Qualigens chemicals, India) and ethanol (500 ml Qualigens chemicals, India) as solvent by employing a soxhlet apparatus seperately until exhaustion. The pooled extract were concentrated under reduced pressure in a Vaccuum evaporator at $40{ }^{\circ} \mathrm{C}$ to get a semi solid residues. Twenty grams of $A$. indica leaf powder was macerated in $200 \mathrm{ml}$ of distilled water on $250 \mathrm{ml}$ Erlenmeryer flasks which were continuously shaken on a rotary at $180 \mathrm{rpm} / \mathrm{min}$ for $24 \mathrm{~h}$ at room temperature. The suspension was filtered using a fine muslin cloth and then through a whatman No: 1 filter paper via a Buchner funnel. The residue was further macerated twice under the same condition. The obtained filtrate of aquoeus extract were mixed and concentrated under vacuum, and then dried by using lyophilizers. The obtained extracts was stored at $4{ }^{\circ} \mathrm{C}$ in air tight bottle until required for a further analysis.

\section{Larvicidal activity}

\section{Stock solution}

0 . $\lg$ of the crude extract (petroleum ether, chloroform, ethyl acetate, n-Butanol, ethanol and aqueous) was dissolved in $1 \mathrm{ml}$ of particular solvent and added 2 drops of Tween 80 . Tween 80 (Qualigens) was used as an emulsifyer. This was made up $100 \mathrm{ml}$ using distilled water. This solution was considered as stock solution $(0 . \mathrm{lg} / 100 \mathrm{ml}, 1000$ $\mathrm{ppm}$ ). From the stock solution of all the six solvent extracts different concentration were prepared with decholorinated water ranging from $1000 \mathrm{ppm}, 2000 \mathrm{ppm}, 3000 \mathrm{ppm}, 4000 \mathrm{ppm}$ and $5000 \mathrm{ppm}$ respectively, and then subjected to Larvicidal bioassay screening.

\section{Collection of larvae}

The Larvae were collected from fresh stagnant water (waste pot, plastic container, plant pot) near D. K. M. College, Garden, Vellore. The Larvae was collected in a plastic container and transferred to the Laboratory immediately and identified. Preliminarily, the identification of the mosquito Larvae Ae. albopictus collected was done in Vector Controlled Research Center (VCRC), Pondicherry. Third instar Larvae alone were collected for the Larvicidal bioassay. Feed to the mosquito larvae was supplied in the mass ratio of $3: 1$ (pedigree dog biscuits and yeast) for its growth.

\section{Larvicidal bioassay}

The larvicidal assay of the $A$. indica extracts was tested against the Ae. albopictus larvae by following the world health organization. The third instar larvae (Ae. albopictus) was used for the larvicidal activity. From the stock solution (1000 ppm of petroleum ether, chloroform,ethyl acetate,-butanol, ethanol, aqueous) ifferent dilutions of $1000 \mathrm{ppm}, 2000 \mathrm{ppm}, 3000 \mathrm{ppm}, 4000 \mathrm{ppm}$ and 5000 ppm were prepared in $250 \mathrm{ml}$ of deionized water. Two controlled groups, one setup containing two drop of tween 80 mixed with 250 $\mathrm{ml}$ of dechlorinated water, and another setup containing $250 \mathrm{ml}$ of dechlorinated water only, were used for testing larvicidal activity. 25 third instar larvae were released into $250 \mathrm{ml}$ of dechlorinated water containing extract solution and control experiment (with tween 80 and without tween 80 ) were run in parallel. All the container were subsequently nylon mosquito netting to prevent mosquito species from egg laying. The extract water solution was stirred for 30 second with a glass rod after appporximately $5 \mathrm{~min} .25$ larvae were transferred gently to the test medium by dropper. Larval food was not given for the test larvae. After $24 \mathrm{~h}$ and $48 \mathrm{~h}$ of exposure mortality rates of larvae were identified when they were unable to move normally after gently touching with needle in the siphon or cervical region. The laboratory test was carried out under the controlled temperature of $\left(26 \pm 2{ }^{\circ} \mathrm{C}\right)$ and relative humidity $(60 \pm 10) \%$. Each tested concentration was replicated two to five trials and the mean of one replicate was recorded in the study. The control mortalities were corrected by using Abbott's formula

$$
\begin{gathered}
\begin{array}{c}
\text { Corrected mortality } \\
\text { Observed mortality in treatment }- \text { Observed mortality in Control }
\end{array} \times 100 \\
100-\text { Control mortality } \\
\text { Percentage mortality }=\frac{\text { Number of dead larvae }}{\text { Total number of larvae }} \times 100
\end{gathered}
$$

\section{Statistical analysis}

The average larval mortality data were subjected to probit analysis for calculating LC50, LC90 and other statistics at 95\% confidence limits of upper fiducidal limit (UFL) and lower fiducidal limit (LFL), and chi-square values were calculated using the SPSS 16.0 version (software package). The values are expressed as mean \pm SD of five replicates. Results with $\mathrm{P}<0.05$ were considered to be statistically significant.

\section{RESULTS}

The results clearly indicate that Petroleum ether extract of $A$. indica exhibited a potent mortality against $3^{\text {rd }}$ instar larvae of Ae. albopictus tested. Petroleum ether extract of $A$. indica was found to be most effective at $5000 \mathrm{ppm}(100 \%$ mortality, both $24 \mathrm{~h}$ and $48 \mathrm{~h})$, where as $4000 \mathrm{ppm}$ found to be more potent and showed $100 \%$ mortality at 48 $\mathrm{h}$ and $90 \%$ at $24 \mathrm{hr}$. Petroleum ether extract at a lowest concentration of $3000 \mathrm{ppm}, 2000 \mathrm{ppm}$ and $1000 \mathrm{ppm}$ killed $50 \%, 40 \%, 50 \%$ respectively, when exposed for $24 \mathrm{~h}$ and $40 \%, 50 \%, 100 \%$ respectively, for $48 \mathrm{~h}$. Petroleum ether extract showed LC50 value of 2805.43 and $2376.11 \mathrm{ppm}$ for $24 \mathrm{~h}$, and $48 \mathrm{~h}$ respectively. The LC90 value of extract was found to be $3825.14 \mathrm{ppm}$ and $3327.80 \mathrm{ppm}$ for $24 \mathrm{~h}$ and $48 \mathrm{~h}$ respectively (table 1,2). The chisquare values were significant at $\mathrm{P} \leq 0.05,0.01$ for $24 \mathrm{~h}$ and $48 \mathrm{~h}$ respectively.

Chloroform extract also recorded a high larval mortality against $3^{\text {rd }}$ instar Ae. albopictus larvae. LC50,LC90 and Chisquare value for $24 \mathrm{~h}$ and $48 \mathrm{~h}$ were also calculated. The data are presented in table 1,2 . It was determined that highest concentration caused $100 \%$ mortality with LC50 value of $2276.5 \mathrm{ppm}$ and $2213.36 \mathrm{ppm}$ on post exposure at $24 \mathrm{~h}$ and $48 \mathrm{~h}$. LC90 value calculated was found to be $4015.8 \mathrm{ppm}$ and $3430.43 \mathrm{ppm}$ at $24 \mathrm{~h}$ and $48 \mathrm{~h}$ respectively. A statistically significant value was also found at $24 \mathrm{~h}$ and $48 \mathrm{~h}$ between control and the extract with a value of at $\mathrm{P} \leq 0.01, \mathrm{P} \leq 0.005$ respectivley.

Table 1, 2 shows the larvicidal activity of n-Butanol extract of $A$. indica against $3^{\text {rd }}$ instar larvae after $24 \mathrm{~h}$ and $48 \mathrm{~h}$ treatment at 1000 ppm-5000 ppm. Among the five different concentration 3000 $\operatorname{ppm}(48 \mathrm{~h}), 4000 \mathrm{ppm}(24 \mathrm{~h}$ and $48 \mathrm{~h})$ and $5000 \mathrm{ppm}(24 \mathrm{~h}$ and $48 \mathrm{~h})$ recorded $100 \%$ larval mortality compared to other concentration recording the LC50 value. The $24 \mathrm{~h}$ showed the highest $\mathrm{LC} 50$ value of about $2276.5 \mathrm{ppm}$ compared to $48 \mathrm{~h} 2213.36 \mathrm{ppm}$. The dose dependent result suggested that the value LC90 was identified as 3628.19 and $2518.86 \mathrm{ppm}$ for Ae. albopictus at $24 \mathrm{~h}$ and $48 \mathrm{~h}$ respectively. The "P" values was significan $\forall(P \quad 0.01,0.01)$ when compared to the control after $24 \mathrm{~h}$ and $48 \mathrm{~h}$ treatment. 
The larval mortality of Ae albopictus after the treatment of ethylacetate extract of $A$. indica was observed. Table 1, 2 provides the result of larval mortality of Ae. albopictus (third instar) after the treatment of $A$. indica ethyl acetate at different concentration (1000 ppm-5000 ppm). No mortality was noted by treatment of $A$. indica at $1000 \mathrm{ppm}, 10 \%$ mortality was noted at $24 \mathrm{~h}$ at $2000 \mathrm{ppm}$, whereas it has been increased to $30 \%$ at $48 \mathrm{~h}$. Similar trend has been noted for $3000 \operatorname{ppm}(30 \%, 24 \mathrm{~h}, 70 \%, 48 \mathrm{~h})$ and $4000 \operatorname{ppm}(40 \%, 24 \mathrm{~h}, 50 \%, 48 \mathrm{~h})$ and $3000 \operatorname{ppm}(60 \%, 24 \mathrm{~h}, 100 \%, 48 \mathrm{~h})$. The LC50 and LC90 values were represented as followed LC50 values of third instar larvae was $4472.14 \mathrm{ppm}$ in $24 \mathrm{~h}$ and the LC90 values of $3^{\text {rd }}$ instar larvae was $2469.61 \mathrm{ppm}$ in $24 \mathrm{~h}$ and $4215.84 \mathrm{ppm}$ in $48 \mathrm{~h}$. The chisquare value significant at $24 \mathrm{~h}(\mathrm{P} \leq 0.01) 48 \mathrm{~h}(\mathrm{P} \leq 0.01)$.

The ethanol and aqueous extract of $A$. indica does not cause any mortality at varying concentrations against the third instar lavae of Ae. albopictus.

Table 1: Percentage mortality at different time interval in larvicidal activity

\begin{tabular}{|c|c|c|c|c|c|}
\hline \multirow[t]{2}{*}{ Extract } & \multirow[t]{2}{*}{ Concentration } & \multicolumn{2}{|c|}{$\%$ mortality at different time interval } & \multicolumn{2}{|c|}{ Mortality percent means $( \pm S E)$ at two intervals } \\
\hline & & $24 \mathrm{~h}$ & 48h & $24 h$ & $48 h$ \\
\hline Petroleum ether & $1000 \mathrm{ppm}$ & 20 & 30 & $20.33 \pm 0.57$ & $30.33 \pm 0.57$ \\
\hline \multirow[t]{4}{*}{ Extract } & $2000 \mathrm{ppm}$ & 40 & 40 & $40.33 \pm 0.57$ & $40.66 \pm 0.57$ \\
\hline & $3000 \mathrm{ppm}$ & 40 & 50 & $50.66 \pm 0.57$ & $51.00 \pm 0.00$ \\
\hline & $4000 \mathrm{ppm}$ & 90 & 100 & $90.33 \pm 0.57$ & $100.00 \pm 0.00$ \\
\hline & $5000 \mathrm{ppm}$ & 100 & 100 & $100.00 \pm 0.00$ & $100.00 \pm 0.00$ \\
\hline \multirow[t]{5}{*}{ Chloroform extracts } & $1000 \mathrm{ppm}$ & 20 & 40 & $19.66 \pm 0.57$ & $40.66 \pm 0.57$ \\
\hline & $2000 \mathrm{ppm}$ & 30 & 40 & $30.00 \pm 1.00$ & $40.33 \pm 0.57$ \\
\hline & 3000 ppm & 70 & 70 & $70.33 \pm 0.57$ & $70.00 \pm 1.00$ \\
\hline & $4000 \mathrm{ppm}$ & 90 & 100 & $89.66 \pm 0.57$ & $100.00 \pm 0.00$ \\
\hline & $5000 \mathrm{ppm}$ & 90 & 100 & $90.00 \pm 1.00$ & $100.00 \pm 0.00$ \\
\hline \multirow[t]{5}{*}{ n-Butanol extracts } & $1000 \mathrm{ppm}$ & - & 10 & $0.00 \pm 0.00$ & $10.00 \pm 1.00$ \\
\hline & $2000 \mathrm{ppm}$ & 20 & 20 & $19.33 \pm 0.57$ & $19.66 \pm 1.52$ \\
\hline & 3000 ppm & 30 & 100 & $30.66 \pm 1.15$ & $100.00 \pm 0.00$ \\
\hline & $4000 \mathrm{ppm}$ & 100 & 100 & $100.00 \pm 0.00$ & $100.00 \pm 0.00$ \\
\hline & $5000 \mathrm{ppm}$ & 100 & 100 & $100.00 \pm 0.00$ & $100.00 \pm 0.00$ \\
\hline \multirow[t]{5}{*}{ Ethyl acetate extracts } & $1000 \mathrm{ppm}$ & - & - & $0.00 \pm 0.00$ & $0.00 \pm 0.00$ \\
\hline & $2000 \mathrm{ppm}$ & 20 & 30 & $20.33 \pm 0.57$ & $29.33 \pm 0.57$ \\
\hline & $3000 \mathrm{ppm}$ & 30 & 70 & $30.66 \pm 1.15$ & $69.66 \pm 0.58$ \\
\hline & $4000 \mathrm{ppm}$ & 40 & 50 & $40.66 \pm 1.15$ & $49.33 \pm 1.15$ \\
\hline & $5000 \mathrm{ppm}$ & 60 & 100 & $60.66 \pm 0.557$ & $100.00 \pm 0.00$ \\
\hline $\begin{array}{l}\text { Ethanol and aqueous } \\
\text { extracts }\end{array}$ & 1000 ppm-5000 ppm & 0 & 0 & $0.00 \pm 0.00$ & $0.00 \pm 0.00$ \\
\hline Control & 1000 ppm-5000 ppm & 0 & 0 & $0.00 \pm 0.00$ & $0.00 \pm 0.00$ \\
\hline
\end{tabular}

Values represent the mean of three replicates. Values are given as mean \pm Standard derivation, ppm indicatesParts per million, h-hour.

Table 2: Larvicidal activity of Acalyphaindicaleaf extract against aedesalbopictus

\begin{tabular}{|c|c|c|c|c|c|c|c|c|c|c|}
\hline \multirow[t]{3}{*}{ Extracts } & \multicolumn{4}{|c|}{ 95\% confidence limits } & \multicolumn{2}{|c|}{ Regression equation } & \multicolumn{2}{|c|}{ Chi-square } & \multicolumn{2}{|c|}{ P value } \\
\hline & \multicolumn{2}{|l|}{$24 h$} & \multicolumn{2}{|l|}{$48 \mathrm{~h}$} & \multirow[t]{2}{*}{$24 h$} & \multirow[t]{2}{*}{$48 \mathrm{~h}$} & \multirow[t]{2}{*}{$24 h$} & \multirow[t]{2}{*}{$48 \mathrm{~h}$} & \multirow[t]{2}{*}{$24 h$} & \multirow[t]{2}{*}{$48 h$} \\
\hline & $\begin{array}{l}\text { LC50(LCL- } \\
\text { UCL) }\end{array}$ & $\begin{array}{l}\text { LC90(LCL- } \\
\text { UCL) }\end{array}$ & $\begin{array}{l}\text { LC50(LCL- } \\
\text { UCL) }\end{array}$ & $\begin{array}{l}\text { LC90(LCL- } \\
\text { UCL) }\end{array}$ & & & & & & \\
\hline $\begin{array}{l}\text { Petroleum } \\
\text { ether }\end{array}$ & $\begin{array}{l}2805.43 \\
(2253.13- \\
3493.18)\end{array}$ & $\begin{array}{l}3825.14 \\
(3688.82- \\
4296.19)\end{array}$ & $\begin{array}{l}2376.11 \\
(1737.07- \\
3250.23)\end{array}$ & $\begin{array}{l}3327.80 \\
(2891.27- \\
3690.76)\end{array}$ & $Y=2.815+0.005 x$ & $Y=2.713+0.054 x$ & 5.36 & 6.18 & 0.05 & 0.01 \\
\hline Chloroform & $\begin{array}{l}2276.5 \\
(1835.23- \\
2823.88)\end{array}$ & $\begin{array}{l}4015.8 \\
(3919.33- \\
4238.28)\end{array}$ & $\begin{array}{l}2213.36 \\
(1896.7- \\
2582.89)\end{array}$ & $\begin{array}{l}3430.43 \\
(3184.72- \\
3846.08)\end{array}$ & $Y=2.087+0.127 x$ & $Y=1.452+0.041 x$ & 3.8 & 7.29 & 0.01 & 0.01 \\
\hline Ethyl acetate & $\begin{array}{l}4472.14 \\
(3831.54- \\
5219.83)\end{array}$ & - & $\begin{array}{l}2469.61 \\
(2179.77- \\
2797.98)\end{array}$ & $\begin{array}{l}4215.84 \\
(4001.19- \\
4675.74)\end{array}$ & $Y=5.285+0.017 x$ & $Y=3.715+0.094 x$ & 4.42 & 8.93 & 0.01 & 0.01 \\
\hline n-butanol & $\begin{array}{l}2777.88 \\
(2490.72- \\
3098.15)\end{array}$ & $\begin{array}{l}3628.19 \\
(3320.22- \\
4087.09)\end{array}$ & $\begin{array}{l}2225.61 \\
(1986.91- \\
2492.99)\end{array}$ & $\begin{array}{l}2518.86 \\
(2279.61- \\
2994.06)\end{array}$ & $Y=3.486+0.066 x$ & $Y=1.897+0.072 x$ & 7.53 & 10.8 & 0.01 & 0.01 \\
\hline
\end{tabular}

LCL-lower confident level, UCL-upper confident level, h-hours, P-Significant, LC50 lethal concentration that kills $50 \%$ of the exposed larvae, LC90 lethal concentration that kills $90 \%$ of the exposed larvae.

\section{DISCUSSION}

In the presence study, effect of $A$. indica leaf extract on Ae. albopictus third instar larvae were compared in terms of relative potential with control. As the result indicated that $A$. indica extract with petroleum ether, chloroform, n-Butanol,ethylacetate, ethanol and aqueous, applied in different concentrations have a different larvicidal effect against third instar Ae. albopictus larvae under laboratory condition. The $3^{\text {rd }}$ instar larvae showed restless movement for short time and then settled at the bottom of the disposable cup and slowly dead.
In the laboratory after $24 \mathrm{~h}$ exposure, the n-butanol and chloroform extracts obtained from the leaf of $A$. indica at 5000 ppm have shown higher percentage mortality while the petroleum ether extract and ethyl acetate extract of $A$. indica had moderate percentage mortality.

The mean percentage mortality of $3^{\text {rd }}$ instar larvae on treatment with n-butanol, chloroform extract at 5000 ppm were $100 \%$ respectively ( $48 \mathrm{~h}$ ). While petroleum ether extract with the sample concentration showed $100 \%$ ( $24 \mathrm{~h}$ and $48 \mathrm{~h}$ ). Where asethylacetate extract of $A$. indicashowed $60 \%(24 \mathrm{~h})$ and $100 \%(48 \mathrm{~h})$. The 
percentage larval mortality of $3^{\text {rd }}$ instar larvae of Ae. albopictus increased as time of exposure increased. Ethanol and aqueous extract of $A$. indica at $1000 \mathrm{ppm}, 2000 \mathrm{ppm}, 3000 \mathrm{ppm}, 4000 \mathrm{ppm}$ and 5000 ppm showed no mortality after $24 \mathrm{~h}$ and $48 \mathrm{~h}$ exposure under laboratory condition. Alwala et al., [29] reported that the methanolic extracts of Mangifera indica exhibited no toxicity while the other extract (aqueous and acetone extract) showed toxicity against $A$. aegypti, dengue vector. The result reveales that the toxic activity may be due to change in the selection of the solvent [30] Similarly, Adebayo et al., [31] examined the bioactivity of methanolic extrats of Mangifera indica leaf against $A$. aegypti and found to be more effective against $4^{\text {th }}$ instar larvae.

From previous report it was found that hexane and chloroform extract from bark of $A$. squamosa showed 84 and $100 \%$ mortality against $4^{\text {th }}$ instar An. stephensis after $24 \mathrm{~h}$ exposure. Kamarajet al., Sukumaret al., [32-33] reported the variation in toxicity against the larval instar may be due to presence of phytochemical compound which varied with plant part,solvent used and the extract concentration.

According to Abbas et al., [34] the larvicidal activity of Tagetesminuta was possible due to the effective components like terpenoids, aglycon, flavanoids and saponin. Similarly, this study showed that the larvicidal effect of $A$. indica was possibly because of alkaloids, flavanoids, Tannin and phenolic compounds, steroids and terpenoids. Also Marcard et al., [35] reported that the larvicidal mortality was positively correlated with concentration and duration of exposure. Similarlyin this study, has the concentration of extract increases from $1000 \mathrm{ppm}$ to $5000 \mathrm{ppm}$, the percentage mortality also increases almost five fold, from initial concentration to final concentration. Several investigators also confirmed positive relationship between larval mortality and time factor [36-39]. As the time of exposure increases, the percentage larval mortality of $3^{\text {rd }}$ instar larvae of Ae. albopictus were also found to be increases. The mortality of petroleum ether and chloroform extract of $A$. indica at $4000 \mathrm{ppm}$ was $100 \%$ after $48 \mathrm{~h}$ exposure. While mortality of $\mathrm{n}$ Butanol extract at 3000 ppm was $100 \%$ after $48 \mathrm{~h}$ exposure. Whereas ethylacetate extract showed $100 \%$ mortality at $5000 \mathrm{ppm}$ after $48 \mathrm{~h}$ exposure under laboratory condition.

This result also illustrated that all different active chemical compound in the leaf part of $A$. indica was responsible for diverse activity against Ae. albopictus. Singh and Prakash, [40] reported that larvicidal activity was observed against $A$. stephensi when six different concentration were used $(5,10,20,30,40$ and $50 \mathrm{mg} / \mathrm{l})$. Similarly in the present study six different concentration were used (1000 ppm, 2000 ppm, 3000 ppm, 4000 ppm and 5000 ppm) against Ae. albopictuws.

In the present study it can be pointed out that leaf of $A$. indica excerted larvidical properties. LC50 ranged from 2777.88 ppm$4472.14 \mathrm{ppm}$ when using n-butanol, chloroform and ethyl acetate as solvent within the $24 \mathrm{~h}$ exposure. A range of LC50 values between 2225.61 ppm-2469.61 ppm within $48 \mathrm{~h}$ exposure period. Sakthivadivel and Thilagavathy, Tang et al., [41,42] has also observed LC50 range value between $30.47 \mathrm{mg} / \mathrm{ml}$ and $13.58 \mathrm{mg} / \mathrm{ml}$ when using petroleum ether extract at $24 \mathrm{~h}$ from seeds of $A$. meucana. However our present investigation observed a low LC50 value (LC50 ranged from $2376.11 \mathrm{ppm}(48 \mathrm{~h})-2805.43 \mathrm{ppm}(24 \mathrm{~h})$ ) when using petroleum ether as solvent from leaf of $A$. indica. Similar a low LC50 value $(20 \mathrm{mg} / \mathrm{ml}-50 \mathrm{mg} / \mathrm{ml})$ were observed by when using hexane extract from seeds of $A$. merxicana and stem bark of $P$. perniciosumat $48 \mathrm{~h}$ exposure respectively. Bilal et al., [43] successful, tested the larvicidal activity of selected plant extracts against $A$. alpopictus. All the extracts showed the moderate activity with a lowest LC50 value at the dose of $363.7,377.5$ and $403.5 \mathrm{mg} / \mathrm{l}$ respectively, for $24 \mathrm{~h}$ and the value get reduced to 263.95, 300.8 and $342.2 \mathrm{mg} / \mathrm{l}$ after $48 \mathrm{~h}$ respectively. As similar to previous research our report also documented a LC50 value of 2276.5, 2777.88, 2805.43 and 4472.14 for $24 \mathrm{~h}$ exposure and the value get reduced to 2225.61, 2213.36, 2376.11 and $2469.61 \mathrm{ppm}$ for $48 \mathrm{~h}$ exposure. Among the tested plant extract n-butanol, chloroform, ethylacetate, and petroleum ether of $A$. indica (leaf) demonstrated remarkable larvicidal activity Ae. alpopictus. Thus this plant extract provide the bases to act as alternative to synthetic insecticide in control programme of mosquito. To avoid the detrimental effects caused by chemical agents against mosquito vector, natural and nontoxic bioactive compound from plant origin can be used as an alternative control agent toward mosquito vectors [44]. Hereby, this study finally proposed a new alternative floral biopesticide in the mosquito management rather than using conventional chemical control. Chemical control is more expensive than the biological control (plant origin) and is also more effective and target specific[45] than conventional chemical control.

\section{CONCLUSION}

In conclusion, this study clearly reveals that $A$. indica leaf extract could be one of the new potential bio larvicidal agent against the vector Ae. albopictus. Therefore the present result also emphazised the need for further research and investigation to isolate and identify the most bioactive compound and there activity against mosquito vector Ae. albopictus.

\section{ACKNOWLEDGEMENT}

The third author thank Science and Engineering Research Board (SERB), Govt. of India for the award of SERB N-PDF (File No. PDF/2015/000375/lS) for financial support.

\section{AUTHORS CONTRIBUTION}

First Author act as a researcher, Second author did data analysis, Third author contributed some financial support for publication and Fourth author acted as supervisior for this work.

\section{CONFLICTS OF INTERESTS}

\section{Declared none}

\section{REFERENCES}

1. Kovendan K, Murugan K, Vincent S, Barnard DR. Studies on larvicidal and the pupicidal activity of LeucasasperaWilld. (Lamiaceae) and bacterial insecticide, Bacillus sphaericus against the malarial vector, Anopheles stephensi Liston. (Diptera: Culicidae). Parasitol Res 2012;110:195-203.

2. Logeswari P, Silambarasan S, Abraham J. Ecofriendly synthesis of silver nanoparticles fromcommercially available plant powders and their antibacterial properties. SciIranica 2013;20:1049-54.

3. Lounibos LP. Invasions by insect vectors of human disease. Annu Rev Entomol 2002;47:233-66.

4. Dharmagadda VSS, Naik SN, Mittal PK, Vasudevan P. Larvicidal activity of Tagetespatula essential oil against three mosquito species. Bioresour Technol 2005;96:1235-40.

5. Carriger JF, Rand GM, Gardinali PR, Perry WB, Tompkins MS, Fernandez AM. Pesticides of potential ecological concern in sediment from South Florida canals: an ecological risk prioritization for aquatic arthropods. Soil Sediment Contam 2006;15:21-45.

6. Kamaraj C, Rahuman AA, Bagavan A. Antifeedant and larvicidal effect of plant extracts against Spodopteralitura (F), Aedesaegypti L. and Culexquinquefasciatus say. Parasitol Res 2008;103:325-31.

7. San Martin JL, Brathwaite O, Zambrano B, Solorzano JO, Bouckenooghe A, Dayan GG, et al. The epidemiology of dengue in the Americas over the last three decades: a worrisome reality. Am J Trop Med Hyg 2010;82:128-35.

8. Jaswanth A, Ramanathan P, Ruckmani K. Evaluation of mosquitocidal activity of Annona squamosa leaves against filarial vector mosquito, Culexquinquefasciatus say. Indian J Exp Biol 2002;40:363-5.

9. Park K. Park's textbook of preventive and social medicine. 20th ed Jabalpur Banarsidas Bhanot Publishers; 2009.

10. Prabhu K, Murugan K, Nareshkumar A, Ramasubramanian N, Bragadeeswaran S. Larvicidal and repellent potential of Moringaoleifera against malarial vector, Anopheles stephensi Liston (Insecta: Diptera: Culicidae). Asian Pac J Trop Biomed 2011;1:124-9.

11. Allison LN, Dike SK, Opara FN, Ezike MN, Amadi AN. Evaluation of larvicidal efficacy and phytochemical potential of some 
selected indigenous plant against Anopheles gambiense and Culexquinquefasciatus. Adv Biosci Biotechnol 2013;4:1128-33.

12. Sharma P, Mohan L, Srivastava CN. Larvicidal potential of Neriumindicum and Thiyaorientelis extracts against malarias and Japanese encephalitis vector. J Environ Biol 2005;26:67-70.

13. Rajkumar S, Jebanesan A. Larvicidal and oviposition activity of Cassia obtusifolia Linn (Family: Leguminosae) leaf extract against malarial vector, Anopheles stephensi Liston (Diptera: Culicidae). Parasitol Res 2009;104:337-40.

14. Pandey SK, Upadhyay S, Tripathi AK. Insecticidal and repellent activities of thymolfrom the essential oil of Trachyspermumammi (Linn) Sprague seeds against Anopheles stephensi. Parasitol Res 2009;105:507-12.

15. Kumar S, Warikoo R, Wahab N. Larvicidal potential of ethanolic extracts of dried fruits of three species of peppercorns against different instars of an Indian strain of dengue fever mosquito, Aedesaegypti L. (Diptera: culicidae). Parasitol Res 2010;107:901-7.

16. Simas NK, Lima Eda C, Kuster RM, Lage CL, de Oliveira Filho AM. Potential use of Piper nigrum ethanol extract against pyrethroid-resistant Aedesaegypti larvae. Rev Soc Bras Med Trop 2007;40:405-7.

17. Govindarajan M. Bioefficacy of Cassia fistula Linn. (Leguminosae) leaf extract againstchikungunya vector, Aedes aegypti (Diptera: Culicidae). Eur Res Med Pharmacol Sci 2009;13:99-103.

18. Harve G, Kamath V. Larvicidal activity of plant extracts used alone and in combination with known synthetic larvicidal agents against Aedesaegypti. Indian J Exp Biol 2004;42:1216-9.

19. Vasudevan K, Malarmagal R, Charulatha H, Saraswatula VL, Prabakaran K. Larvicidal effects of crude extracts of dried ripened fruits of piper nigrum against Culexquiquefascitus larval instars. J Vector Borne Dis 2009;46:153.

20. Morita H, Tomizawa Y, Deguchi J, Ishikawa T, Arai H, Zaima K, et al., Synthesis and structure-activity relationships of cassiarin A as potential antimalarials with vasorelaxant activity. Bioorg Med Chem 2009;17:8234-40.

21. Kamaraj C, Rahuman AA, Bagavan A, Zahir AA, Elango G, Kandan $\mathrm{P}$, et al. Larvicidal efficacy of medicinal plant extracts against Anopheles stephensi and Culexquinquefasciatus (Diptera: Culicidae). Trop Biomed 2010b;27:211-9.

22. Dua VK, Pandey AC, Dash AP. Adulticidal activity of essential oil of Lantana camera leaves against mosquitoes. Indian J Med Res 2010;131:434-9.

23. Dua VK, Gupta NC, Pandey AC, Sharma VP. Repellency of Lantana camera (Verbenaceae) flowers against Aedes mosquitoes. J Am Mosq Control Assoc 1996;12:406-8.

24. Gratz NG. Critical review of the vector status of Aedesalbopictus. Med Vet Entomol 2004;18:215-27.

25. Liu XC, Liu QY, Zhou L, Liu QR, Liu ZL. Chemical composition of Zanthoxylumavicennae essential oil and its larvicidal activity on Ae. albopictus Skuse. Trop J Pharm Res 2014;13:399-4.

26. Yadav R, Tyagi V, Tikar SN, Sharma AK, Mendki MJ, Jain AK, et al. Differential larval toxicity and oviposition altering activity of some indigenous plant extracts against dengue and chikungunya vector Ae. albopictus. J Arthropod Borne Diseases 2014;8:174-85.

27. AkonoNtonga P, Baldovini N, Mouray E, Mambu L, Belong P, Grellier P. Activity of Ocimumbasilicum, Ocimumcanum, and Cymbopogoncitratus essential oils against Plasmodium falciparum and mature-stage larvae of Anopheles funestus. Parasite 2014;21:33.

28. Benelli G, Canale A, Conti B. Eco-friendly control strategies against the Asian tiger mosquito, Ae albopictus (Diptera: Culicidae): repellency and toxic activity of plant essential oils andextracts. Pharmacologyonline 2014;1:44-51.
29. Alwala OJ, Wanzala W, Inyambukho RA, Osundwa EM, Ndiege IO. Characterization and evaluation of repellent effect of essential oil of Mangiferaindica L. from Kenya. J Essen Oil Bear Plants 2010;13:85-96.

30. Mohammed A, Chadee DD. An evaluation of some trinidadian plant extracts against larvae of Ae. aegypti mosquitoes. J Am Mosq Control Assoc 2007;23:172-6.

31. Singh G, Prakash S. Efficacy of Bacillus sphaericusagainstlarvae of malaria and filarial vectors: an analysis of early resistance detection. Parasitol Res 2009;104:763-6.

32. Sakthivadivel M, Thilagavathy D. Larvicidal and chemosterilant activity of the acetone fraction of petroleum ether extract from ArgemonemexicanaL seed. Bioresour Technol 2003;89:213-6.

33. Kamaraj C, Bagavan A, Elango G, Abduz Zahir S, Rajakumar G, Marimuthu S, et al. Larvicidal activity of medicinal plant extracts against Anophelessubpictus and Culextritaniorhynchus. Indain J Med Res 2011;134:101-6.

34. Adebajo AC, Famuyiwa FG, Aliyu FA. Properties for sourcing. Nigerian Larvicidal Plants 2014;19:8363-72.

35. Sukumar K, Perich MJ, Boobar LR. Botanical derivatives in mosquito control: a review. J Am Mosq Control Assoc 1991;7:210-37.

36. Hadjiakhoondi A, Vatandoost H, Khanavi M, Abaee MR, Karami $M$. Biochemical investigation of different extracts and larvicidal activity of Tagetesminuta L. on Anopheles stephensi larvae. Iran J Pharm Res 2005;1:81-4.

37. Marcard M, Zebitz CPW, Schmutterer H. The effect of crude methanol extract, Ajugasp on post embryonic development of different mosquito species. J Appl Entomol 1986;101:146-54.

38. Tonk S, Bartarya R, Kumari K, Bhatnagar V, Strivastava S. Effective method for extraction of larvicidal component from leaves of Azadirachta indicaand Artemisia annua Linn. J Environ Biol 2006;27:103-5.

39. Abdul Rahuman A, Bagavan A, Kamaraj C, Vadivelu M, Abdu Zahir A, Elango G, Pandiyan G. Evaluation of indigenous plant extracts against larvae of Culexquinquefasciatus say (Diptera: Culicidae). J Parasitol Res 2008;104:637-43.

40. Mullal K, Jebanesan A, Pushpanathan T. Mosquitocidaland repellent activity of the leaf extract of Citrullus vulgaris (Cucurbitaceae) against malaria vector, Anopheles StephensiListon (Diptera: Culicidae). Eur Rev Med Pharmacol Sci 2008;12:1-7.

41. Abdu Zahir A, Abdul Rahuman A, Kamaraj C, Bagavan A, Elango G, Sangaran A, et al. Laboratory determination of efficacy of indigenous plant extracts for parasites control. J Parasitol Res 2009;436:1-5.

42. Tang LIC, Ling APK, Koh RY, Chye SM, Voon KGL. Screening of anti-dengue activity in methanolic extracts of medicinal plants. BMC Complementary Altern Med 2012;12:3.

43. Bilal H, Akram W, Din S, Khan IA, Hassan SA, Arshad M. Larvicidal activity of selected plant extracts against Aedes albopictus skuse (Diptera: Culicidae). Afr Entomol 2012;20:8-12.

44. Das NG, Goswami D, Rabha B. Preliminary evaluation of mosquito larvicidal efficacy of plant extracts. J Vector Borne Dis 2007; 44:145-8.

45. Jaenson TG, Pålsson K, Borg-Karlson AK. Evaluation of extracts and oils of mosquito (Diptera: Culicidae) repellent plants from Sweden and Guinea-Bissau. J Med Entomol 2006;43:113-9.

\section{How to cite this article}

- Ashwini U, Taju G, Thirunavukkarasu P, Asha S. Pupal emergence inhibition activity of Acalypha indica leaf extract against dengue vector, Aedes albopictus mosquito. Int J Pharm Pharm Sci 2017;9(8): 114-118 